\title{
The Pre-History of the Paleo Diet: Cancer in Nineteenth-Century Britain
}

\author{
Agnes Arnold-Forster
}

Dr Loren Cordain describes himself as the 'world's foremost authority on the evolutionary basis of diet and disease' and as 'one of the world's leading experts on the natural human diet of our Stone Age ancestors.' ${ }^{1}$ He is the self-proclaimed founder of the Paleo Diet Movement and champions a way of eating that mimics that of our hunter-gatherer forbears. As its online advocates perform their commitment to this arcane way of eating through the very modern mediums of blogging, Twitter and Instagram, the popular Paleo diet and its cousins seem closely tied to the peculiarities of the twenty-first century. And yet, the Paleo premise is not new. In 2014, Cordain published an article on his website, titled 'Breast Cancer and Other Cancers: Diseases of Western Civilization?'2 In it, he claims that cancer was 'rare or non-existent in historically studied hunter gatherers and other less westernized peoples'. In support of this, he quotes various early-twentieth-century authorities, including the Nobel prizewinning physician Dr Albert Schweitzer, who wrote on his arrival in Gabon in 1913, 'I was astonished to encounter no case of cancer ... This absence of cancer seemed to me due to the difference in nutrition of the natives as compared with the Europeans. ${ }^{3}$

This quotation, which Cordain takes as near-irrefutable evidence, provokes him to insist at the end of the article, 'Any way you look at it, the Paleo Diet is a good remedy to prevent cancer.' It is unusual for someone positioning themselves as a contemporary scientific authority to make use of, and directly quote, historical sources - not as errors to be refuted but as evidence for their claims. What are not unusual, however, are the assumptions that underlie the cancer-preventing claims of the Paleo diet. It is a wellknown, if ill-supported, trope that cancer constitutes a 'pathology of progress' - an unintended consequence of modernity. Or, as Charles Rosenberg puts it, 'The notion that the incidence of much late-20th-century chronic disease reflects a poor fit between modern styles of life and humankind's genetic heritage. ${ }^{5}$ His seminal article on 'the idea of civilization as risk' identifies a tendency on behalf of late-twentieth-century critics to point to the structured asymmetry between a body evolved in Paleolithic conditions and the late-twentieth-century environment in which that body must maintain itself'. However, he suggests that the conventions of this argument - that the 'change from savage to settled rural and then to urban life brought with it conditions 
increasingly inimical to the body's requirement for diet, exercise, and stable emotional surroundings' - were already established by the end of the eighteenth century.

However, while Rosenberg devotes considerable attention to the nineteenthcentury origins of the ideas about the perceived health dangers of urban, industrial society, he focuses on infectious diseases and emotional disorders. Cancer and other chronic diseases, he argues, are instead assumed to be products of the last 50 years, 'At the end of the twentieth century, many of the same themes and anxieties have recast themselves in rather different form. Our most invisible anxieties have surfaced in regard to chronic disease, not neurosis or hysteria. ${ }^{6}$ Rosenberg is not alone in locating our preoccupation with cancer as a problem of civilization in the late twentieth century and neglecting its nineteenth-century genesis. While Roy Porter called cancer 'the modern disease par excellence' and Siddhartha Mukherjee described it as 'the quintessential product of modernity', they locate that modernity firmly in the post-war period. ${ }^{7}$ Thus, cancer in the nineteenth century - in general - also remains understudied. ${ }^{8}$ What work that has been produced on the disease's history has predominantly focused on the twentieth century. This asymmetry can be partly explained by the ways in which cancer has been constrained by a version of periodization that serves to tie certain maladies - or malady-types - to specific epochs. Medical historians, epidemiologists and demographers have conceptualized the nineteenth century as the 'epidemic century', with infectious diseases and their control occupying the forefront of historical investigation. This periodization is most clearly articulated by Abdel Omran's 'citation classic', published in 1971, on the theory of epidemiological transition. ${ }^{9}$ He posited three phases: 'the age of pestilence and famine' - roughly corresponding to medieval and early modern Europe; 'the age of receding pandemics' - the long nineteenth century; and 'the age of degenerative and man-made diseases' - intimately associated with civilization and the development of 'modern' healthcare and medicine. ${ }^{10}$ Diet is at the centre of this narrative. Civilized ways of living bring civilized ways of eating which, in turn, bring civilized diseases.

Yet, and as Cordain has noticed, the idea that 'civilized' ways of eating made certain races more susceptible to cancer has its roots in the nineteenth century. The collection of vital statistics in Britain from the 1840s onwards suggested to troubled observers that cancer's incidence was increasing exponentially. This perceived 'cancer epidemic' captured the medical and lay imagination, and provoked intense debate. Even the fashion magazine Vogue despaired, 'It is sad news indeed that cancer is increasing at such a rate.'11 This chapter thus explores fin-de-siècle debates about the relationship between industrialized or civilized life and cancer incidence to address this historiographical lacuna. Specifically, it argues that British discourse about the 'cancer epidemic' orbited around anxieties over social and economic progress and attendant dietary change. This discourse centred on two questions. First, had the broad chronological sweep of civilization - from hunter-gatherer to Western industrialization - made certain races more or less susceptible to cancer? 'Negro' communities (in nineteenth-century parlance) appeared to be immune to the disease, whereas Anglo-Saxon races - situated at the apex of Victorian conceptions of civilization - seemed particularly prone. Could the answer to this hierarchy be found in their food? Second, had more short-term shifts in diet dramatically effected the cancer incidence of certain countries? For example, 
had changes in diet following the Irish famine (increase in processed food and lowquality American meat) accelerated Ireland's cancer susceptibility?

Various historians have observed that this period witnessed an increased awareness of food as a potential vector for disease. ${ }^{12}$ Moreover, some scholars have recognized the close historical relationship between diet and cancer. For example, David Cantor has argued that for many early-twentieth-century Americans, cancer was a disease of nutrition and particularly a product of meat consumption. ${ }^{13}$ Similar ideas circulated in fin-de-siècle Britain. Like Cantor, I argue that the close connection between cancer and diet was in part a product of how practitioners and the public understood the disease's pathology and character. However, while he suggests that this association proved troublesome for later-twentieth-century public health and awareness-raising campaigns, I contend that the causal relationship between food and malignancy appealed to, and was reassuring for, a professional community otherwise despairing at their impotence in the face of this 'dread disease'.

This chapter is divided into two parts. Part One clarifies what cancer was in latenineteenth-century Britain and delineates how Victorian practitioners and the public conceptualized its causes, characteristics, and cures. It also provides context to explain the broader connections made between food, diet and malignancy in this period. Part Two shows how fin-de-siècle medical men constructed expansive spatial and temporal hierarchies and argued that the broad chronological sweep of civilization - from the Stone Age to late-nineteenth-century modernity - had structured races' susceptibility to cancer. Specifically, it looks at how, as diets moved further from 'nature', they were thought of as increasingly 'cancer causing. Finally, it zeroes in on a specific case study Ireland after its famine - taken up by late-nineteenth-century observers as an example of how declining quality of food and the increase in the importing of foreign produce were undermining the cellular integrity of a population.

\section{Nineteenth-century cancer}

Cancer in the nineteenth century was identified and diagnosed according to its observed adherence to a set of characteristics. It was, like today, defined by its long duration and its irreversible capacity for growth and spread. Those surgeons who felt surface cancer with their hands were well aware that these masses could be later-stage manifestations of an internal disease; or that breast cancer, for example, could spread to the liver or lungs. Crucially, too, it was a material entity - an 'object' that could be identified by hand or eye. ${ }^{14}$ Cancer was evidenced by the presence of a tumour, accompanied by pain, physical degeneration and disability, and marked by its inexorably increasing magnitude. ${ }^{15}$ These identifying characteristics were codified following cancer patients' admission to the nineteenth-century hospital, after two cancer-specific institutions were set up in 1792 and $1802 .{ }^{16}$ The context of the clinic allowed medical men to trace cancer through its life course, making possible extended observations of its duration and its tendency to grow and metastasize. Then, practitioners watched their subjects die with depressing regularity. Thus, the hospital confirmed cancer as an incurable disease that was 
distinct from other maladies. Early-nineteenth-century surgeon Thomas Denman insisted, 'Of all diseases deemed incurable, that which is denominated Cancer has been most generally allowed to be so.' ${ }^{\prime 7}$

While many of these identifying features of the disease might be alien to us today, we can nonetheless meaningfully speak of 'cancer' as a broadly coherent and stable disease category in the nineteenth century and before. Historian Alanna Skuse argues that while cancer in the early modern period was predicated on an entirely different way of interpreting the human body and its afflictions, it nonetheless had much in common with our twenty-first-century malady: cancer then is recognizable to us now. She claims that 'cancerous disease "existed" in the early modern period, in the sense of there being a distinctive malady known as "cancer" which was broadly contiguous with the illness sharing that name today. ${ }^{18}$ In the nineteenth century, too, cancer was a distinct pathological entity that shared physical characteristics with the malady in both the sixteenth century and the twenty-first. This stable profile over time, at least in terms of its meaning if not its experience, only makes cancer's relative absence from the historical literature more surprising.

While many other diseases ended in death in the nineteenth century, cancer was articulated as superlative - as the most extreme case on a spectrum. The language used by medical men and the laity alike repeatedly reinscribed this special status. Cancer was synonymous with 'malignancy' - an evocative term that meant both the ability to metastasize and a being with malevolent intention. Cancer was positioned as a disease that was not only deadly, but also cruel. It was a 'pernicious' malady, synonymous with death and decline and feared by doctor and patient. ${ }^{19}$ It was, 'of all the ills to which the human frame is liable', the 'most poignant. ${ }^{20}$ It was repeatedly designated the 'crudele opprobrium medicorum' - the cruellest challenge to the medical profession.

The terms here have a moral inflection, and it was common for commentaries on cancer - or commentaries that used cancer metaphorically - to describe the disease as something with agency and independence of thought. These metaphors also inscribed a connection between malignancy, food and eating. For centuries, cancer had been conceptualized as a parasitical being - a creature occupying the body and consuming it from within. In her article on malignancy in early modern England, Skuse describes how in the seventeenth century, the disease was imagined as 'quasi-sentient, zoomorphising the disease as an eating worm or wolf. ${ }^{21}$ This idea that cancer was an animal, distinct from its host, persisted into the nineteenth century. It was endowed with character, temperament and disposition - with needs in direct competition with those of the body it occupied. In 1841, a Member of Parliament claimed, 'The unjust and miserable system of paying wages out of rates - the discouragement of industry, and the premium which was offered to improvidence and sloth - the cancer which has got such a powerful hold of the southern provinces, was gradually eating its way to the heart of England [my emphasis]. ${ }^{.22}$ Metaphors and analogies are rhetorical or analytical techniques, but they also articulate actual scientific and medical understanding. ${ }^{23}$ In other words, for these cancer metaphors to 'work' in the political context of Parliament, they needed to have some widespread purchase on the collective imagination. That MPs could deploy such language to rhetorical effect was dependent on a general understanding of cancer as having intention and being animal-like. 
This notion that cancer was a parasite was intimately linked to a prevalent idea that the disease was much affected by the diet of its host. In the 1890s, a doctor called cancer 'an independent organism, like many a protozoon; that lives a life which is wholly independent and proper to itself'. ${ }^{24}$ Not only was it conceptualized as a semiindependent life form, one that required its own system of sustenance, but the disease was frequently described using metaphors of food and consumption. In 1910, Charles Walker, from the Glasgow Royal Cancer Hospital, pointed out that 'cancer cells derive their nourishment from the cells forming the body of the organism in which they exist.' ${ }^{25}$ Their 'vitality' was well known, so 'any change of diet must affect the [cancer] cells. ${ }^{26}$ It was therefore unsurprising to a fin-de-siècle commentator that after the 'female secondary sexual organs', cancer of the stomach was the 'commonest form of the disease in both sexes. ${ }^{27}$

Thus, the connections drawn between cancer and diet were not just metaphorical. Towards the end of the nineteenth century, food and drink were increasingly offered as explanations for the cancer's origin. For while practitioners had made substantial headway in observing and codifying the disease, its causes remained largely unknown. This acknowledge limitation to medical knowledge, combined with the fear and anxiety associated with the incurable 'dread disease', prompted a wide-ranging search for explanatory models for its aetiology. In 1902, Dr James Braithwaite suggested in the British Medical Journal that cancer was caused by an 'excess of salt in the diet.' ${ }^{28}$ Similarly, a pair of contemporaneous colonial doctors claimed that tea drinking was to blame for the disease's incidence in New Zealand. ${ }^{29}$ The second half of the nineteenth century witnessed diet becoming an increasingly popular explanatory mechanism for cancer and its origin. This was no coincidence and depended not only on a widespread perception that the incidence of cancer was increasing, but also on persuasive contemporary anxieties over racial difference, the unintended costs of civilization and dietary innovation.

\section{The cancer epidemic}

The 1840 s and 1850s saw the British populace increasingly quantified. This practice derived in part from the development of statistical methods and epidemiology, and grew alongside a numerical study of people and their activities more generally. ${ }^{30}$ The main source of vital statistics was the Annual Report of the Registrar-General on Births, Deaths and Marriages in England, first presented to Parliament in $1838 .{ }^{31}$ The General Registry Office (GRO) calculated the annual mortality by each cause and the proportion of deaths in 100,000 effected by each class of disease in each region. Narrative prefaces to each annual report situated individual investigations within a broad chronology and enabled doctors and public health professionals to comment on yearly shifts in the disease profile of the nation..$^{32}$ From the Fourth Annual Report causes of death were recorded, alongside the person's sex, age and profession. The causes were divided into 'Epidemic, Endemic, and Contagious Diseases', 'Sporadic Disease of Uncertain or Variable Seat', 'Sporadic Diseases of Special Systems and Organs' and 'External Causes: Poisoning, Asphyxia, Injuries'. Cancer was categorized 
within 'Sporadic Disease of Uncertain or Variable Seat. ${ }^{33}$ In 1879, the narrative preface to the Forty-Second Annual Report reported that there appeared to be a new 'cancer epidemic' in Britain, and that the disease had 'maintained the increase to which it has been gradually mounting for many years.. ${ }^{34}$ This new 'cancer epidemic' prompted an array of rival explanatory models and investigative strategies, including spatial configurations of the disease on a global scale.

Thus, and in part because science and medicine were key components of British imperial expansion, by the closing decades of the century, a dynamic and interactive network of scientists and doctors was working in colonial contexts. Men like W. Renner, medical officer of Freetown; Sierra Leone; and Sir William MacGregor, lieutenantgovernor of British New Guinea, compiled data and anecdotes about cancer incidence in their respective countries and reported them back to the metropole..$^{35}$ London-based journals like the British Medical Journal and The Lancet acted as nexuses of cancer information, sent in from across the empire. This information fed into conceptual cartographies of cancer that covered the globe. Commentators theoretically plotted populations on a gradient - from immune to cancer-riddled - with sub-Saharan African communities at one end and Anglo-Saxon or Teutonic races at the other. 'Observation has shown that cancer has a certain geographical distribution. It prevails extensively in some parts of the globe, and is scarcely known in others. ${ }^{36}$

This 'mapping' suggested that England and its Anglo-Saxon inhabitants suffered the greatest burden, 'Englishmen may be regarded as unfortunate; for within the geographical area of these islands cancer asserts largely its malignant and fatal influence. ${ }^{37}$ In contrast, cancer incidence in British colonies was low, even nonexistent. In 1906, the British Medical Journal reported, 'There can be no doubt that cancer in natives of British Central Africa is of the utmost rarity. ${ }^{38}$ Repeated efforts made by Government medical officers throughout the country for some time past have so far resulted in the discovery of but a single case. ${ }^{39}$ The situation in Sierra Leone was similar, 'Cancer as a disease is very rare among the aborigines . . . I would rather not say that the aborigines are immune from the disease, but that the disease is rare among them. ${ }^{30}$ Dr A. J. Craigen, writing from Port Moresby in New Guinea in 1905, reported 'that during his stay of nearly four years in the Possession he has not yet seen a single case of cancer among the native population. ${ }^{41}$ Cancer rates were slightly higher in Hong Kong. 'The returns made to the Registrar-General show that the total number of deaths among the Chinese in the period 1895-1904 was 11, giving an annual deathrate from cancer of 4.45 per 100, 000 of population. ${ }^{42}$ However, as Dr Francis Clark, acting principal civil medical officer, pointed out, this compared 'very favourably with the death-rate from the same cause in England. ${ }^{43}$ These colonial observations of cancer proved troubling to social and medical commentators. Not only was the disease on the increase, but the epidemic seemed to be confined to nations that were conventionally understood as biologically, culturally and economically superior.

The observation that so-called 'primitive' races were relatively immune to cancer required explanation. The idea that certain groups were inherently more or less vulnerable to certain diseases was a common concept in Victorian medicine and it was in part dependent on a version of biological anthropology that structured strict and impermeable boundaries between different races. ${ }^{44}$ This period witnessed a 
concretization of racial distinctions and a heightened commitment of the importance of biology in dictating behaviours and tendencies. This coincided with, and was causally linked to, an increasingly rapacious and fretful imperialism. Late-nineteenthcentury anthropology dictated that race was 'no arbitrary idea, no abstraction'- and practitioners toyed with the idea that cancer was also a product of inherent biology. Surgeon Leo Loeb reflected, 'Whether those differences in the cancer morbidity are primarily questions of race or whether they are due to the external conditions under which the races live. 45

However, and as demonstrated by discourses of dietary innovation, for most finde-siècle commenters cancer was less a product of the civilized body and more of the civilized way of living. Director of the Imperial Cancer Research Fund, E. F. Bashford, insisted that there was nothing intrinsic in the biology of 'Negroes' that made them immune to cancer - nor, as some people suggested, had they been infected by contact with cancer-carrying colonialists - but rather it was due to their conditions of life. $\mathrm{He}$ wrote, 'I venture to assert that the prevalence of cancer among the negroes of America was not brought about contact with cancer-infested white men ... Cancer was inherent in the negroes when they were shipped from their native Africa, where it probably existed as it still does to-day, in natives removed from civilisation. ${ }^{36}$ Eating was central to ideas about the civilized versus the uncivilized lifestyle. The army surgeon William Hill-Climo wrote in 1903, 'There is a strong presumption that it is the food which is at fault. ${ }^{37}$

Hill-Climo and his co-professionals understood 'uncivilized' people as less vulnerable to malignancy because they lived in harmony with the natural world and pursued simple, abstemious habits. These communities tended to avoid decadent or artificial food, tracked closely to nature and so avoided cancer. Surgical registrar to the Middlesex Hospital, W. Roger Williams wrote in 1902, 'The reputation of Egypt for comparative immunity from cancer is well founded... The conditions of existence are unfavourable to the development of cancer. If I am asked to define these conditions, it may be answered that they comprise extreme frugality in living; open-air existence, and last - but not least - an alimentation which includes but little animal food. 48 The low incidence of cancer in Egypt could be explained by its inhabitants' uncivilized lifestyles - its stable cancer epidemic was a product of the country's static relationship with nature and its stationary position on the gradient of societal progress.

A key aspect of nineteenth-century racial anthropology was that difference was not just spread spatially, but temporally as well. 'Primitive' races did not just exist in farflung places, but showed 'civilized' observers how their own societies had once been. They were 'survivals' from bygone eras and revealed the stages of human development. Thus, the geographical distribution of cancer incidence helped explain the increasing rates in Britain. Hill-Climo argued that the increasing death rate from cancer in all European countries, and in the United States, could not be 'ascribed to local or accidental causes', but must instead be 'sought for in the growth of new conditions ... common to all the affected countries, which the people themselves have produced. ${ }^{49}$ The new epidemic was a product of 'new conditions' - and they were conditions of the societies' own making. Hill-Climo's comments relied upon, and in turn confirmed, pervasive contemporary anxieties over the degeneration and decline of 'civilized' 
societies and the inherent dangers of modernity. Coupled with the observed rise in cancer incidence, global geographies of cancer fed into anxieties about the unintended costs of civilization.

The idea of degeneracy, hereditary or otherwise, suffused fin-de-siecle culture and the discourse of Europe's urban elite - and with it the idea that prosperity, industrialization and urbanization brought with them a plethora of physical and emotional complaints. Anxieties over the dangers inherent in industrialized, artificial and urban life were widespread and much has been written about the late-nineteenthcentury preoccupation with 'diseases of modern life'. Dr James Crichton-Browne spoke in 1860 of the 'velocity of thought and action' now required, and of the stress imposed on the brain by being forced to process in a month more information 'than was required of our grandfathers in the course of a lifetime. ${ }^{50}$ Charles E. Rosenberg has argued that concern for the 'psychic dangers of an artificial and emotionally fevered life' had become conventional by the mid-century. ${ }^{51}$ Commentators observed an increase in diseases from worry, overwork, mental or physical strain, excess, self-abuse, stimulants and narcotics. They diagnosed neurosis, hysteria and melancholy on a mass scale, and articulated modern, urban life as inherently risky. This body of literature dealt with the 'apparent paradox' that civilization itself 'might be the catalyst of, as much as the defence against, physical and social pathology'. In an early-twentieth-century New York Times article entitled 'Is Race Extinction Staring Us in the Face?', the author recounted how 'the possibility of the extinction of the human race is predicted by many presentday scientists. They insist that tendencies toward race degeneracy are actively at work.' The author interviewed the founder of the popular cereal brand John Harvey Kellogg, who responded in frantic terms, 'In many large centres of population, Manchester, Eng., for example, it is impossible to find men big enough to serve as policemen.'

These ideas of social and somatic decline in fin-de-siècle Europe and North America primed practitioners to express cancer as a consequence of social and somatic degeneration. Historians have described a society preoccupied with inheritance, atavism, evolution and eugenics, and the cancer story can be mapped on to these anxieties. Indeed, much of Kellogg's fretful commentary centred on cancer as a 'by-product of civilisation. ${ }^{52} \mathrm{He}$ wrote how, over the past 30 years, 'the mortality from chronic diseases has doubled' and cited 'the rapid spread of cancer in both man and the lower animals as an instance of a degenerative malady characteristic of civilization., ${ }^{53}$ There was, therefore, something carcinogenic in civilized habits and ways of eating.

However, there was some disagreement over what precisely constituted the carcinogenic element of civilized dietary change. There was a popular strand of thought that located the cause of cancer - and its increased incidence - in the consumption of meat, and various doctors, food scientists and social commentators - including Kellogg - advocated for vegetarianism as a preventative measure against malignancy, as well as against a whole range of other maladies. ${ }^{54}$ Others found fault not in the type of food, but in the volume. An article published in the British Medical Journal in 1900 argued, 'The abundance of food, which is one of the results of our national prosperity, is on the whole a most powerful factor in the improvement of the public health. But the high standard of general nutrition thus maintained appears to be not without its drawbacks. ${ }^{55}$ Thus, the increase in the number of deaths from cancer was 
due to the 'overeating which is almost universal even among the poorer classes of the population. ${ }^{56}$ Some suggested that the increasing incidence of the disease in civilized nations was because the societies that inhabited them had departed from nature and 'natural' ways of living. This was evidenced by cases of 'primitive' people who appeared to have contracted cancer after deviating from their 'primitive' existence. William Macgregor wrote, 'Dr Johnson ... tells me that in Lagos during a practice of fourteen years' duration, he has five times seen cancer in native patients, and that in each case the sufferer had lived as Europeans live. ${ }^{57}$ Thus, Kellogg recommended that while 'we need not return to savagery to be healthy', we 'must see that the air we breathe is as clean as that which the savage breathes, that the food we eat is as wholesome and pure as the water we drink. ${ }^{58}$

Ireland offered an intriguing case study for late-nineteenth-century commentators on the relationship between dietary innovation and malignant disease. The Great Famine, or the Great Hunger, was a period of mass starvation, disease and emigration in Ireland between 1845 and 1852. As Ian Miller has argued, Irish eating habits changed dramatically between the famine and the country's independence in $1922 .{ }^{59}$ A perceived increase in the incidence of cancer is an underexplored consequence of this change. Army surgeon William Hill-Climo mulled over the relatively low, but nonetheless rising, cancer incidence in Ireland. For while the disease was less common among Celtic communities than its English counterparts, it nonetheless appeared to be increasing: 'It is clear that two questions require to be investigated; the first is that cancer has steadily increased in Ireland during the past 40 years, and the second is that the mortality is much lower than in England and in Scotland. ${ }^{60}$ His answer to both these questions, 'paradoxical as it may appear', was the 'poverty of the Irish people.61 He harked back to an imagined, prelapsarian phase in Irish history: 'Before the Irish famine the Irish lived on oatmeal porridge, potatoes, eggs and milk, with fish and home-cured bacon occasionally. ${ }^{62}$ Hill-Climo believed that this simpler, less decadent diet was less likely to initiate cancer.

However, he lamented that the Irish had lost touch with their wholesome culinary past; 'Now, cheap American bacon and flour pancakes cooked in bacon fat, Indian meal porridge sweetened with chemically-coloured beet sugars, and boiled tea are the stable food commodities of the people. ${ }^{63}$ This quotation reveals a complex coalescing of anxieties over food, cancer, national borders and imperial coherence. Some were concerned by the potentially pathological results of importing refrigerated meat to the British Isles from overseas dominions and other countries. In 1897, the MP for Dorset North, Mr Wingfield-Digby, proclaimed in the House of Commons that 'the consumers of frozen meat were liable to cancer and other terrible diseases. ${ }^{\prime 4}$ Hill-Climo shared in this specific anxiety over meat and argued that 'cancerous diseases ... are caused by the long-continued consumption of unwholesome animal food. ${ }^{65}$ Although it was unclear what he thought had corrupted this animal food - was it something inherent in the animal-ness of the product, its overseas passage or its foreignness?

The bacon, porridge and tea that Hill-Climo was worried about were all foreign products, imported into Ireland across expanses of land and sea. He was distressed at the 'want of variety' in the food and its unwholesomeness. He argued that the imported flour was 'inferior' and 'wanting in freshness.6 ${ }^{6}$ This could reveal a generic anxiety over 
anything alien and introduced from elsewhere. However, it is telling that he noted that the process by which these goods had arrived in Ireland was dependent on 'modern economic conditions. He blamed technological change, claiming that the shift in diet had 'been facilitated by steam transport'. ${ }^{67}$ Hill-Climo was evidently troubled by the possibility that communication and transport technologies - the very fabric of British success and imperial dominion - may well be the source of its undoing. The Irish departure from their 'natural' diets, facilitated by technologies that imported civilization and its attendant consumables from countries like the United States, had made them vulnerable to cancer.

\section{Conclusion}

By 1914, the notion that cancer was an unintended consequence of civilization was well-travelled terrain. A range of observers concluded that not only did a society's location on the global hierarchy of social development determine its susceptibility to malignancy, but also recent transformations in the way inhabitants of the British Isles ate had contributed to a new 'cancer epidemic'. These ideas depended on a variety of interweaving threads of nineteenth-century medical and cultural thought. Cancer was conceptualized as a parasitical being, with its own demands on the host body's system of nutrition. The fin de siècle witnessed widespread anxiety over 'diseases of modern life' and particularly over the role of food as a potential vessel and vector of ill health. Moreover, cancer's stubborn incurability and the persistent mystery over its aetiology made the disease an attractive subject for debate. Its identity, although fixed in some ways, was malleable in others and could be co-opted to support a range of conceptualizations about bodies, societies, and disease.

Moreover, this explanatory model - that negatively correlated 'nature' and the natural with cancer - was powerful if paradoxical. While cancer - with all its attendant horror and suffering - should be an unequivocal negative, it seemed, in the nineteenth century, to imply positive things about the societies in which it flourished. Mapping the global distribution of cancer had suggested that 'Negroes' biologically inferior in every other way - were almost immune to the disease. Cancer incidence thus subverted the conventional hierarchy between colonizers and colonized and found in 'savage' lifestyles a fundamental redeeming feature. Nineteenth-century medical practitioners and Dr Loren Cordain alike tie cancer to modernity - and to a modernity of our own making. Our reckless decadence has made chronic disease common. You might think this critique of civilization - this celebration of non-Western diets - would work to upset conventional hierarchies. However, and as Kellogg pointed out, no one wants to return to 'savagery'. Instead, we live in a strange world in which cancer is a marker of social progress and civilization - an inversion of the expected order. It is not uncommon for public health practitioners today to comment on increases in chronic disease in low- and middle-income countries as a 'sign of success. ${ }^{68}$ This strange world is a Victorian inheritance, an inheritance that Cordain, for all his flaws, acknowledges. 


\section{The Pre-History of the Paleo Diet: Cancer in Nineteenth-Century Britain}

1 'Dr. Loren Cordain', http://thepaleodiet.com/dr-loren-cordain/, accessed 29 September 2017.

2 'Breast Cancers and Other Cancers: Disease of Western Civilization?', http:// thepaleodiet.com/breast-cancer-and-other-cancers-diseases-of-western-civilization/, accessed 29 September 2017.

3 Ibid.

4 Ibid.

5 Charles E. Rosenberg, 'Pathologies of Progress: The Idea of Civilization as Risk', Bulletin of the History of Medicine 72, no. 4 (1998), 714.

6 Ibid., 273.

7 Roy Porter, The Greatest Benefit to Mankind. A Medical History of Humanity from Antiquity to the Present (London: Fontana Press, 1999), 574; Siddhartha Mukherjee, The Emperor of All Maladies: A Biography of Cancer (New York: Scribner, 2011), 241.

8 There are, of course, exceptions. Frances Burney's 1811 mastectomy has received detailed scrutiny from feminist scholars such as J. Epstein and S. Mediratta: J. E. Epstein, 'Writing the Unspeakable: Fanny Burney's Mastectomy and the Fictive Body', Representations 16, no. 1 (1986), 131-66; S. Mediratta, 'Beauty and the Breast: The Poetics of Physical Absence and Narrative Presence in Frances Burney’s Mastectomy Letter (1811)', Women: A Cultural Review 19, no. 2 (2008), 188-207. Cancer and gender in the nineteenth century has also been studied: I. Löwy, "Because of Their Praiseworthy Modesty, They Consult Too Late": Regimes of Hope and Cancer of the Womb, 1800-1910', Bulletin of the History of Medicine 85 (2001), 356-83; O. Moscucci, 'Gender and Cancer in Britain, 1860-1910: The Emergence of Cancer as a Public Health Concern', American Journal of Public Health 95, no. 8 (2005), 1312-21; Gender and Cancer in England, 1860-1948 (Basingstoke: Palgrave Macmillan, 2016). Finally, cancer in nineteenth-century America has received more attention than in the United Kingdom: R. A. Aronowitz, Unnatural History: Breast Cancer and American Society (Cambridge: Cambridge University Press, 2007).

9 George Weisz and Jesse Olszynko-Gryn, 'The Theory of Epidemiologic Transition: The Origins of a Citation Classic', Journal of the History of Medicine and Allied Sciences 65 (2010), 287-326.

10 Abdel Omran, 'The Epidemiological Transition: A Theory of the Epidemiology of Population Change', The Milbank Quarterly 83 (1971), 731-57.

11 Anon., 'Cancer Increasing at an Alarming Rate', Vogue, 15 April 1909, 726.

12 For example, contemporary concerns that contaminated milk communicated typhoid. See, Jacob Steere-Williams, 'The Perfect Food and the Filth Disease: Milk-Borne Typhoid and Epidemiological Practice in late Victorian Britain', Journal of the History of Medicine and Allied Sciences 65, no. 4 (2010), 514-45; and Keir Waddington, 'The Dangerous Sausage: Diet, Meat and Disease in Victorian and Edwardian Britain', Cultural and Social History 8, no. 1 (2011), 51-71.

13 David Cantor, 'Confused Messages: Meat, Civilization, and Cancer Education in the Early Twentieth Century', in Meat, Medicine and Human Health in the Twentieth Century, ed. David Cantor, Christian Bonah and Matthias Dörries (London: Pickering \& Chatto, 2010), 111. 
14 Leukaemia and other malignancies that do not manifest tumours or growths were not defined as cancers in the nineteenth century. It was only in the early twentieth century that they were designated cancers. See, Emm Barnes Johnstone and Joanna Baines, The Changing Faces of Childhood Cancer: Clinical and Cultural Visions Since 1940 (Basingstoke: Palgrave Macmillan, 2015).

15 Scholars have argued that in the eighteenth century, the 'externally unbounded' body became offensive and modernity became increasingly implicated in the practice of disciplining the corporeal. The messy, disorganized cancerous body posed, therefore, a fundamental challenge to the creation of the new 'bourgeois body' in the long nineteenth century. See, Barbara Duden, The Woman beneath the Skin: A Doctor's Patients in Eighteenth-Century German, trans. Thomas Dunlap (Cambridge, MA: Harvard University Press, 1991), 13.

16 These were the Cancer Ward at the Middlesex Hospital in 1792, and 'The Society and Institution for Investigating the Nature and Cure of Cancer' in 1802. Both were established in London. See, John Howard, The Plan Adopted by the Governors of the Middlesex-Hospital for the Relief of Persons Afflicted with Cancer: With Notes and Observations (London: H. L. Galabin, 1792); Bruce Schoenberg, 'A Program for the Conquest of Cancer: 1802, Journal of the History of Medicine and Allied Sciences XXX (1975), 3-22.

17 Thomas Denman, Observations on the Cure of Cancer, with Some Remarks upon Mr. Young's Treatment of That Disease (London: E. Cox, 1816), 3.

18 Alanna Skuse, Constructions of Cancer in Early Modern England: Ravenous Natures (London: Palgrave Macmillan, 2015), 25.

19 John Abernethy, Surgical Observations on Tumours (London: Longman, Hurst, Rees, Orme, and Brown, 1811), 74.

20 Thomas Pope, 'On Cancer', Association Medical Journal 3 (1855), 859.

21 Alanna Skuse, 'Wombs, Worms and Wolves: Constructing Cancer in Early Modern England', Social History of Medicine 27 (2014), 632.

22 HC Deb 08 February 1841 vol 56 cc375-451.

23 See, Laura Otis, 'The Metaphoric Circuit: Organic and Technological Communication in the Nineteenth Century', Journal of the History of Ideas 63, no. 1 (2002), 127.

24 Henry T. Butlin, 'Carcinoma Is a Parasitic Disease. Being the Bradshaw Lecture Delivered before the Royal College of Surgeons of England', British Medical Journal 2 (1905), 1566.

25 Charles Walker, 'Theories and Problems of Cancer: Part III', Science Progress in the Twentieth Century 7, no. 26 (1912), 223-238, 228.

26 Ibid.

27 Woods Hutchinson, 'The Cancer Problem: Or, Treason in the Republic of the Body', The Contemporary Review, July 1899, 113.

28 James Braithwaite, 'Excess of Salt as a Cause of Cancer', British Medical Journal 2 (1902), 1376.

29 P. W. Hislop and P. Clennell Fenwick, 'Cancer in New Zealand', British Medical Journal, 2 (1909), 1225.

30 See, John M. Eyler, 'The Conceptual Origins of William Farr's Epidemiology: Numerical Methods and Social Thought in the 1830s', in Times, Places, and Persons: Aspects of the History of Epidemiology, ed. Abraham M. Lilienfeld (Baltimore, MD: Henry E. Sigerist Supplements to the Bulletin of the History of Medicine 4, 1980), Ian Hacking, The Taming of Chance (Cambridge: Cambridge University Press, 1990); Eileen Magnello and Anne Hardy, eds, The Road to Medical Statistics (Amsterdam: Brill, 2002). 
31 Edward Higgs, 'Registrar General's Reports for England and Wales, 1838-1858', Online Historical Population Reports, http://histpop.org/, accessed 13 October 2016.

32 Edward Higgs, 'The Annual Report of the Registrar-General, 1839-1920: A Textual History', in The Road to Medical Statistics, ed. Eileen Magnello and Anne Hardy (Amsterdam: Brill, 2002), 55.

33 George Graham, 'Statistical Nosology', Fourth Annual Report of the Registrar-General (England, 1840-1841), 93-105.

34 Brydges P. Henniker, 'Introduction', Forty-Second Annual Report of the RegistrarGeneral (England, 1879), xxx.

35 William MacGregor, 'An Address on Some Problems of Tropical Medicine', The Lancet 156 (1900), 1055-61; W. Renner, 'The Spread of Cancer among the Descendants of the Liberated Africans or Creoles of Sierra Leone', British Medical Journal 2, no. 2075 (1910), 977-84.

36 Hugh P. Dunn, 'The Increase of Cancer', Pall Mall Gazette, 12 May 1884.

37 Ibid.

38 H. Herasey, 'The Rarity of Cancer among the Aborigines of British Central Africa. Squamous Carcinoma: Acinous Carcinoma: Physiological Reasons for Immunity from Cancer of the Breast: Columnar Carcinoma', British Medical Journal 2, no. 2396 (1906), 1562-63, 1562.

39 Anon., 'Cancer in the Colonies', British Medical Journal 1 (1906), 812.

40 Renner, 'The Spread of Cancer among the Descendants of the Liberated Africans or Creoles of Sierra Leone', 588.

41 Anon., 'Cancer in the Colonies', 812.

42 Ibid., 812.

43 Ibid.

44 In his 1883 'Address in Pathology', the parasitologist Charles Creighton wrote that smallpox was 'peculiarly an African disease'. This particularity was a biological one 'the loathsomeness, the peculiar odour, and the no less peculiar scars of small-pox, might of themselves suggest another skin than ours.'

45 Leo Loeb, 'The Cancer Problem', Interstate Medical Journal XVII (1910), 1.

46 E. F. Bashford, 'An Address Entitled Are the Problems of Cancer Insoluble?', British Medical Journal 2 (1905), 1510.

47 William Hill-Climo, 'Cancer in Ireland: An Economic Question', The Empire Review VI (1903), 410.

48 W. Roger Williams, 'Cancer in Egypt and the Causation of Cancer', British Medical Journal 2 (1902), 917.

49 Hill-Climo, 'Cancer in Ireland', 411.

50 https://diseasesofmodernlife.org/, accessed 25 August 2017.

51 Rosenberg, 'Pathologies of Progress', 718.

52 Macgregor, 'An Address on Some Problems of Tropical Medicine', 979.

53 Anon., 'Is Race Extinction Staring Us in the Face?', New York Times, 15 October 1911, 11.

54 'An anti-toxic diet, that is a diet which discourages the development of putrefactive poisons in the intestine, is specially to be commended as a means of combating cancer ... During the last 45 years the writer has had unusual opportunities for observation in relation to the influence of a non-flesh dietary upon the occurrence of cancer. Of many thousands of flesh-abstainers with whom he has been acquainted, he has known during this period of only four cases of cancer in persons who had been for a long time flesh abstainers... There can be no doubt that among the thousands of 
persons under observation who escape the disease, as the writer believes through flesh abstaining, there must have been a considerable number who were especially susceptible to cancer because of heredity and who were able to overcome this special susceptibility by a non-flesh dietary.' John Harvey Kellogg, The New Dietetics, What to Eat and How: A Guide to Scientific Feeding in Health and Disease (Battle Creek: Modern Medicine Publishing Co., 1921), 793.

55 Anon., 'Overeating and Cancer', British Medical Journal 1, no. 2045 (1900), 596.

56 Ibid.

57 Macgregor, 'An Address on Some Problems of Tropical Medicine', 982.

58 Anon., 'Is Race Extinction Staring Us in the Face?', 11.

59 Ian Miller, Reforming Food in Post-Famine Ireland: Medicine, Science and Improvement, 1845-1922 (Manchester: Manchester University Press, 2014).

60 Hill-Climo, 'Cancer in Ireland: An Economic Question', 413. Commenters from Linnaeus to Lapouge suggested European populations could be separated along biological lines. Mediterranean peoples were understood as physically inferior 'Homo Alpinus' rather than 'Homo Europaeus' - and seen as closer in quality to the less-civilized races of warmer climes. Northern Italians sometimes said that Calabria evoked Africa; the South was cast as a form of 'other' world. Daniel Pick, Faces of Degeneration. A European Disorder, c. 1848-1918 (Cambridge: Cambridge University Press, 1989), 114. The Irish were similarly racialized, caricatured in the British press with simian noses, long upper lips, huge projecting mouths and sloping foreheads. L. P. Curtis, Apes and Angels: The Irishman in Victorian Caricature (Washington, DC: Smithsonian Books, 1971), 29.

61 Hill-Climo, 'Cancer in Ireland: An Economic Question', 413.

62 Anon., 'Cancer in Ireland: An Economical Question', British Medical Journal 2 (1903), 1544.

63 Ibid.

64 HC Deb 07 April 1897 vol. 48 cc677-711.

65 In their review of Hill-Climo's argument, the British Medical Journal was deeply unimpressed that 'such an important medical proposition' had been first printed 'in a lay journal, in which it cannot be conveniently subjected to skilled criticism. They recognized the impact such a claim could make on the imaginations of the Empire Review's middle-class readership. While they were damming about the veracity of Hill-Climo's claims, the damage had been done. Anon., 'Cancer in Ireland: An Economical Question', 1544.

66 Hill-Climo, 'Cancer in Ireland: An Economic Question', 414.

67 Ibid., 413.

68 'Chronic Diseases Are Killing More in Poorer Countries', https://www.nytimes. com/2014/12/04/world/asia/chronic-diseases-are-killing-more-in-poorer-countries. html?_r=0, accessed 30 September 2017.

\section{Nutrition, Starvation and Diabetic Diets: A Century of Change in the United States}

1 Thursday, 25 January, 10:00 am, discussion at University of Texas San Antonio, Retama Auditorium, San Antonio, Texas. 